pallet, and the nut-collar screws down as much as it rose during the preceding interval of freedom when the action is regular; and the central or main escapement-shaft turns in the same period as the tooth, being the period of the pendulum. If throurh increase or diminution of the driving-power, or dimination or increase of the coefficient of friction between the governing masses and the ring on which they press, the shaft tends to tum faster or slower, the nut collar works its way down or up the screw, until the governor is again regulated, and rives the same speed in the altered circumstances. It is casy to arrange that a large amount of regulating power shall be inplies in a single tum of the nut collar relatively to the central shaft, and yet that the periodic application and removal of about $\frac{1}{10}$ of this amount in the haif period of the pendulum shall cause but a very small periodic variation in the speed. The latter important condition is secured by the great moment of inertia of the governing masses themselves round the main shaft. My communication to the Royal Society ended as follows :-

"I hope after a few months' trial, to be able to present a satisfactory report of the performance of the clock now completed according to the principles explained above. As many of the details of execution may become mocifined after practical trial, it is unnecessary that I should describe them minutely at present. Its general appearance, and the arrangement of its characteristic parts, may be understood from the photograph now laid before the Society."

I am sorry to say that the hope here expressed has not hitherto been realised. Year after year passed producing only more or less of radical reform in various mechanical details of the governor and of the fine movement, until about six months ago, when, for the first time, $I$ had all except the pendulums in approximately satisfactory condition. By that time I had discovered that my choice of zinc and platinum for the temperature compensation, and lead for the weirht of the pendulums was a mistake. I inad fallen into it about ten years ago through being informed that in Russia the gridion pendulum had been reverted to because of the difficulty of getting equality of temperature throughout the length of the pendulum; and without stooping to perceive that the right way to deal with this difficulty was to face if and rake means of securing practical equality of temperature throughout the length of the pendulum (which it is obvious may be done by simple enough appliances), I devised a pendulam in which the compensation is produced by a stiff tube of zinc and a platinum wire placed nearly parailel each to the other throughout the length of the pendulum. The two pendulums of the clock shown to the British Association were constructed on this plan. Now it is clear that the materials chosen for compensation should, of all those not otherwise objectionable, be those of greatest and of least cxpansibility. Therefore, certainly, glass or platinum ought to be one of the materials, and the steel of the ordinary astronomical mercury pendulum is a mistake. Mercury ought to be the other (its cubic expansion being six times the linear expansion of zinc) unless the capillary uncertainty of the mercury surface lead to irregular changes in the rate of the pendulum. The weight of the pendulum ought to be of material of the greatest specific gravity attainable; at all events unless the whole is to be mounted in an air-tight case ; because one of the chief errors of the best existing pendulums is that depending on the variations of barometric pressure. The expense of platinum puts it out of the question for the weight of the pendulum, even although the use of mercury for the temperature compensation did not also give mercury for the weight. Thus even though as good compensation could be got by zinc and platinum as by any other means, mercury ought on account of its superior specific gravity (nearly three times that of lead) to be preferred to lead for the weight of the pendulum.
I have accordingly now made several pendulums (for tide-gauges) with no other material in the moving part than glass and mercury, and with rounded knife edges of agate for the fixed support; and I am on the point of making four more for two new clocks which I am having made on the plan. which forms the subject of this communication. I have had no opportunity hitherto of testing the performance of any of these pendulums, but their action seems very promising of good results, and the only untoward circumstance which has hitherto appeared in connection with them has been breakages of the glass in two attempts to have one carried safely to Genoa for a tidegange made by Mr. White, to an order for the Italian Government.

As to the accuracy of my new clock, it is enough to look at the pendulum vibrating with perfect steadiness, from month to month, through a range of half a centimetre on each side of its middle position, with its pallets only touched during $\frac{1}{30}$ of the time by the escapement-tooth, to feel certain that, if the best ordinary astronomical clock owes any of its irregularities to variations of range of its pendulum or to impulses and friction of its escapementwheel, the new clock must, when tried with an equally good pendulum, prove more regular. I hope soon to have it tried with a better pendulum than that of any astronomical clock hitherto made, and if it ther shows irregularicies amounting to $\frac{1}{10}$ of those of the best astronomical clocks, the next step must be to inclose it in an air-tight case kept at constant temperature, day and night, summer and winter.

\section{ON THE TROPICAL FORESTS OF HAMPSHIRE}

FNGLAND at the present time has a climate far from tropical, but at the time to which this lecture refers the palm and spice plantis flourished here; and hence tie climate then may rightly be spoken of as actually tropical.

The dita on which this inference is based are the fosid leaves which are found in the clays of the south of Hampshire. Out of the many thousands of such leaves obtained by me during summer holidays for many years past, some selected specimens were exhibited in a cabinet in the Loan Coliection of Scientific Instruments. Other collections of leaves from this spot and from Alum Bay have been madi, and may be seen in the British Museum. It is the district immediately along the line east and west of Bournemouih which has been specially exanined, and it is in the lower Bagshot beds, which are, comparatively speaking, amongst the youngest of the geological scale, that the leaves referred to have been found.

These Bagshot beds need not detain us; but as I have referred to them as amongst the youngest in the geological scale, I may mention that above them we have the Bracklesham beds, full of marine forms; the Barton beds, also full of marine forms, but telling a tale of a different sea; the Headon, Bembridge, and Hempstead series, with many repetitions of marine and fresh-water conditions, indicating long lapses of time. There is, too, the whole Miocene period, of which we have no trace in this district, but which we believe from continental evidence was of vast duration. Then, too, there followed periods of immense length, during which England underwent its latest glacial epoch; after that, the time during which the gravels were formed. While, thcrefore, we speak of these beds as almost the youngest of our series, they belong to periods of an incalculably remote past.

It is from the cliffs principally, and from the deep cuttings of the recently constructed railway from Bournemouth to Parkstone, that our knowledge is mainly derived. There are, in addition, the diggings carried on

I Lecture in connection with the Loan Collection of Scientific Apparatus, given at the South Kensington Museum, December 2 I8 76 , by J. Starkie Gardner, F.G.S. 
for commercial purposes. Great interest attaches to these somewhat monotonous-looking cliffs, as it is from them that has been unearthed the marvellously rich flora which I shall briefly describe further on. Let us commence by visiting the diggings near Wareham. We see that they are situated on a wild moorland with hillocks, under the high range of chalk downs, in a gap in which stand the massive ruins of Corfe Castle. Very bleak and barren the scenery looks in high winds and driving showers, and the latter are of unusually common occurrence, the clouds being caught and held by the high downs. The moorland stretches far to the sea and enwraps Poole Harbour, continuing as far as the eye can reach, beyond Bournemouth to the tower of the fine old abbey of Christchurch and to the New Forest, being here and there clothed with extensive pine plantations. But in fine weather it has a charm of its own and is especially lovely when the yellow furze and purple heather are in full bloom. Even the actual diggings themselves are most picturesque, especially those now abandoned, as there we find little deep blue lakes surrounded by manycoloured cliffs fifty feet in height, in which bright yellows, magentas, and crimsons predominate. I do not apply the word blue to the small lakes poetically, for they are of an intense blue, finer in colour than the famed biue of the waters of some of the Swiss lakes. The heath is, in some patches, of a magenta colour, where a crimson clay patch forms the soil. If we examine these cliffs and banks we find them composed of clays dark or white, or red and white mottled, of layers of coarse grey grit and of sands of every shade of red and yellow, white, and variegated. Often the sands have angular lumps of clay imbedded in them. The quarrying is mostly done in open pits, the clay being dug out perpendicularly with a long and narrow spade. Some of the deeper seams are mined, and a considerable depth is reached in Mr. Pike's work. ings, and at Branksea it is worked under the sea-level. These pipeclays are exported to all parts of the world wherever good pottery is made.

Overlying the pipeclays we find another series of deposits, which are not here quarried for use, but looked upon as refuse; but near Bournemouth they are dug into in many places for the brick earth contained in them. They are easily distinguished by the darker colour and more sandy nature of the clays. These drab clay basins are of smaller extent and are full of remains of decayed leaves, and have actual seams of coal in them, which is burnt by the villagers. We now cross Poole Harbour, at high tide a magnificent shest of water, the distant bills, behind which the sun sets, giving it the appearance of an Italian lake, and glance at Branksea Island as we pass-the owner of which, however, will not allow us to land. In the sheltered bay of Studland we can see but little of the cliffs, as they are now mostly overgrown to the very beach. We are struck, however, by the coloured sands which forcibly remind those of us who are familiar with them of the still more brilliant hues of the sands at Alum Bay.

Being ferried across the inlet of Poole Harbour and walking along the beach towards Bournemouth, we find the coast for the first mile composed of hills of blown sand, beyond which the cliffs we have been viewing from a distance rapidly rise. These cliffs are themselves of rather monotonous appearance, being devoid of the brilliant colouring so conspicuous at Alum and Studland Bays, but they are crowned for the greater part of their length with pine woods. Their colour varies from buff to white and from white to slate colour. We notice apparently endless successions of clays, sands, and grits deposited at clifferent angles and without any single bed being traceable for more than a few yards. The cliffs, preserving the same characters for a distance of four miles, extend to near Boscombe, where we notice a change in their composition. The clays are black and still more sandy, the upper parts of the cliffs are far less steep and seem composed of loose white sands and shingle with a thick capping of gravel.

At length still further east these beds disappear beneath the sea in consequence of the general dip of the strata. The sand beds which follow, where they cap the cliffs, are recognised from a great distance by their greater slope from the cliff shorewards, for they are so loosely composed that every wind blows the sand away in clouds and leaves the shingle to rattle down on to the beach. So loose is this material that that part of the coast line which had cliffs composed of this sand has now but an insignificant height ; all the sand has been blown away by wind and wasted by rain, until the shingle has been left dropping lower and lower, and the stones which neither wind nor rain could affect, have come closer and closer together. This is the cause of the land connecting Hengistbury Head being much lower than any other in the neighbourhood. The shingly beds are ancient sea beaches, and the slope of them to the ancient sea can still be seen in places. So long have they been exposed that the flint pebbles in them are sometimes almost decomposed, the familiar white coating to the flints being an inch or move thick. This shingle, which is composed of rounded pebbles, that tell the tale of a long rolling on the old sea beach, is now the source of the pebbles on the present beach, and the round condition of the pebbles on the present beach on this part of the coast is not as on the shore further towards Poole, or as at Brighton, the result of present wave action, although the existing sea has undoubtedly reduced the pebbles in size. They cannot be confounded with the later angular river gravels which every where cover this area.

At the peninsula of Hengistbury Head, about six miles beyond Bournemouth, the cliffs again rise, being at first composed of black, chocolate-coloured, and white sands with pebbles, and farther on of green clayey sands containing nodules of large irregularly-shaped concretions of sandy, argillaceous ironstone disposed in layers, until lately worked for iron and shipped to the smelting furnaces of South Wales. Beyond Christchurch Harbour we have cliffs of white sand which, according to my views, close the series.

Inland the country has a barren appearance except in the plantations, and the scattered brick pits afford no additional information of use to us in our present researches. There is but little of interest to the tourist except on the very edges of the district where the archreologist will be interested in the Minsters of Christchurch, with its associated ruins, Wimborne, and the ruins of Corfe Castle.

No order of arrangement is at first apparent in these beds, but by going backwards and forwards over the ground attentively there is, it seems to me, a very wellmarked and recognisable sequence. I will now tell you what I take to be this sequence. It has never been submitted to geologists before, and it is possible, as is often the case with new work, that there may be some objections raised to it.

FRESHWATER. MAFINE

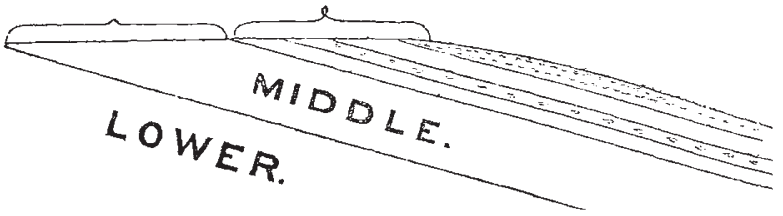

F G. x.

I would refer to the diagram (Fig. I) where I have expressed my reading of this district. This lower fresh-water series is seen in the neighbourhood of Corfe and forms part of the cliffs at Studland. It is characterised by abundance of pipeclays, and has a thickness of 200 feet or more.

The middle freshwater series, also met with near Corfe 


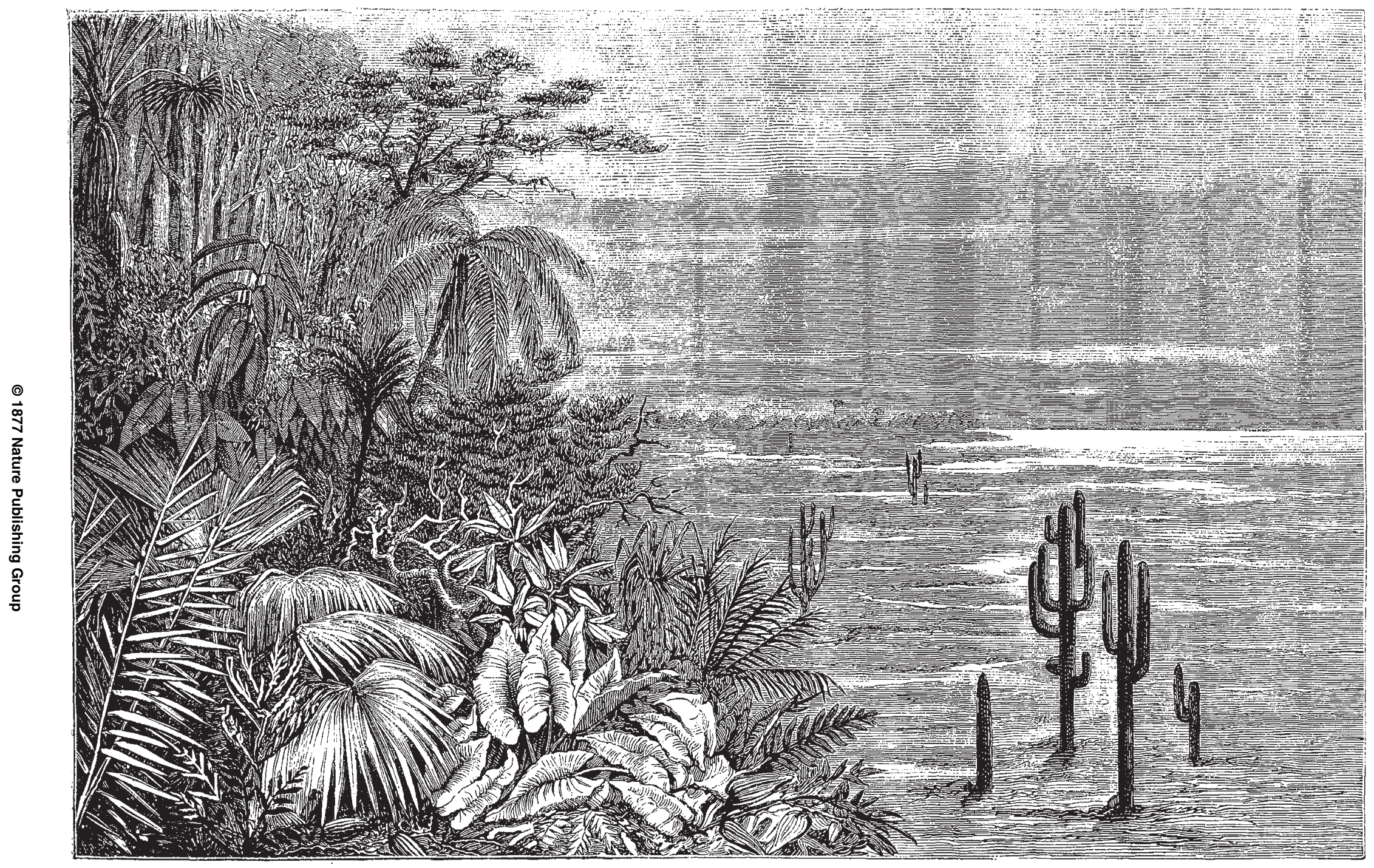

Fva. 2. The Valley of the Bourne restored to represent the conditicns which are supposed to have existed during the deposition of the Lower Bagshot Formation From a drawing used in illustration of 
and at Studland, forms the whole thickness of the cliffs between Poole Harbour and Bournemouth. We thus have a magrificent section four miles long and roo feet in height. Branksea Island is also formed of this series. Their entire thicliness cannot yet be accurately stated, but may be put down at some 300 feet. They are characterised by the fact that the clays containcd in them are usually brick-earth.

The next series above is a marine series and is some 400 or: 500 feet thick. The base beds are dark sands and clays, succeeded by pebble beds and sands, then more sandy clays with pebbles, and ending with a thick deposit of white sands. This marine portion of the series occupies the cliffs between Boscombe and High Cliff.

Plain as this order of deposition appears, we have collateral proof that this interpretation is right, for at Alum Bay there is a complete section of the whole of these beds although somewhat thinned out, upheaved vertically, that is, turned completely on end, so that we can examine them in detail in the space of a few hunàred yards, like passing in review volumes on a book-shelf. We see in succession the lower pipe-clays, the brilliant sands, the darker clays, sands, pebblebeds, one after the other, so tilted up and so placed that those who know nothing of the depression and elevation of areas can with difficulty be brought to believe that they have all been deposited horizontally.

In griving you the history of the deposition of these beds, I shall have to speak of a sinking area, and before doing so let me remind you that in Lyell's "Geology," a book in everyone's hands, many instances are recorded, of sinking areas in historic times, from our knowledge of which we feel justified in supposing that there were sinking areas in geological times.

The thick pipeclays and quartzose grits which we find at the bottom of the series can without the slightest hesitation be referred to the result of the wearing away of granite rock, for wherever granite is woin away by water, there we find white clays and similar quariz grits. We need not go further than Cornwall to see still finer clays, which have been produced in quite recent times from granite by the agency of water. The beds of this district included in the Tertiaries, frot laid down over the challs, were those now called London clay (a marine deposit), and when the streams which brought down our Bagshot beds first spread out their deposits, they spread over the London clay, except, pernaps, in those places where they first cut away the London clay, so that some of these Bagshots were possibly laid down on the chalk. The water in this case came from the west, and as here we are nearer the hills, which were the source of the clay, we find the grits coarser and the clays thicker.

At Studland the grits are not so coarse, and at Alum Bay, a long way east, the sands are very fine, so that anyone knowing the district could tell which of these specimens came from either place.

Each clay-patch represents a small lake, first scooped. by the running water out of the beds just previously deposited, and then filled in by sediment. The mode of action is this :- The weather disintegrates the exposed surfaces of the distant granite rocks, and the looscned particles are carried by rain into streamlets, which convey them on to the river. The river, tearing and tumbling along, grinds the rocks which have fallen into its bed into round boulders, until in flood times the water is white with finely-divided granite. This grit being hurried along by the rush, is spread far and wide over the valley whenever the stream bursts its banks, which mountain torrents very often do, while the finer particles are still held and carried on until a lake or pool is met with, where the speed is checked; these fine particles are then dropped, and the water becomes quite clear. This deposition of fine clay goes on for ages, until the lake becomes filled up, the water gets diverted into another channel, and what was a lake becomes dry land; the river at the next flood spreads over the valley, covers in common with the surrounding ground what was the lake again and again with thick grits. Such is the origin of the large basins containing the clays which serve now to make your pipes and your crockery. You have only to recornise that the valley in which this takes place was slowly sinking, and there is no limit to the thickness of sands and clays which might be thrown down on any one spot, and in this way can be explained the sudden changes from grit to clay, which would else be a puzzle to us. The size of these old lakes is very well sem now wherever a clay basin has been quarried away, for tho clay is quarried away for use whilst the sand is left. Some of them are represented by the beautiful blue pools I told you about, and are seen, therefore, to have been about one-quarter to one-third of a mile round, whilst their depths have varied from 30 to 60 feet. Mr. Lawrence Pike informs me that other clay basins arc of larger extent, being $\frac{3}{4}$ of a mile in diameter. Their greatest length is in the direction of the valiey. These clays extend under the surface, eastward, for they are worked at Branksea under the sea-level, at Parkstone, and near Bourne. At Alum Bay they are tilied up, and are full of beautiful fossil leaves.

This next series of beds above, which $I$ have told you are of a clifferent character, mark a great change in the conditions of the land. The clay patches are of smaller extent, being the filling in of mere ponds or puddles, which acted on a smaller scale, as the lakes of which we have just spoken. The change indicated by these beds is one from the valley in which the previous contained beds were deposited, to a broad low-lying tract in prosimity to the sea. We infer that we can trace how this tract became gradually lowered and lowered down to the sealevel.

The belief in the gradual lowering of the land in this area is borne out by the fact that in the cliffs near boole, which are shightly lower in position than those fartien east, we get only leaves of evergreens and forest tices, whilst as we work our way east so as to moet with beds on a higher level or, which is the same thing, of more recent a se, we get a mixture of fems and other plants, which require rinch moisture, whilst farther east still we get assemblages of plants that could only have lived in absolut: swaines.

Low as the land appears to have become we have no evidence whatever, throughout the whole thickness of this part of the series, amounting to 300 feet at least, win an exception which I will tell you about directly, that it was low enough to be inundated by the sea, as the few shells that have been found are of fresh-water kinds. The exception alladed to is the occurrence of $\log 5$ of wood bored by the ship-worm or teredo. All the ship-worms generally known to us live only in salt water, and are so delicately organised that the slightest mixture of fresh water instantly kills them. This isolated fact for some time presented a grave difficulty, but happening to read Mr. Gwyn Jeffreys' interesting account of the habits of this creature, I not only found that he relates the occurrence of similarly bored wood 300 miles up the River Gambia, but distinctly states that there is a species which lives in fresh water. Therefore this supposed marine indication may be on his authority removed, and, supposing this theory should be verified and universally accepted, we may safely infer that these middle beds are of fresh-water origin.

We now come to the third series of beds. A still continued sinking of the area brought this swampy condition so low that the sea was no longer kept out, but, bursting through, formed great salt-water lagoons teeming with life ; for we suddenly. find crowds of marine forms imbedded in what was formerly black mud, such as we might find now in the existing Poole Harbour bere. 
In this series of marine beds we have at the bottom lagoon beds, as I call them, which may represent a similar state of things to what we see at Christchurch, or Poole, or Weymouth, or any place where we have mud banks lift a or ven? Shallow, between each returnise tide. We still find here leaves of trees, many of them doubtless wrinanging the lagoons, which have so slowly decayed, that they are overgrown with zoophytes; crowds of oysters are met with; we find the remains of shorecrabs, which from our knowledge of existung species, we infer, overran the muddy shore; the callianassa, a prawn-like creature, which bored through the mud; limpets, arcas, corbulas, and many other shell-bearing molluses, passing their lives, dying, and becoming buried in the sediments of the sheltered lagoons. This lagoon condition went on until the gradual sinking has permitted the ever-encroaching surf to break over the lagoon barrier, to rush in, and in time overwhelm them with rolled shingle and sea-sand. We still trace the lagoon condition for a inile or so east, where it is represented by cigar-ash coloured sands, impregnated with salt, and coloured with this dark tint of carbonaceous matter. These sands contain very perfect remains of branches of a coniferous

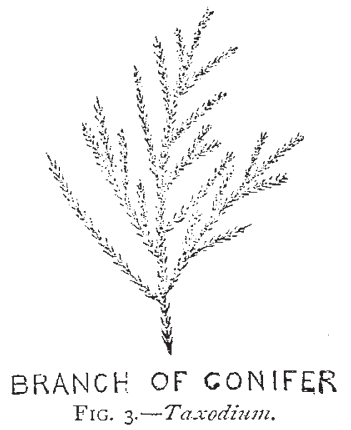

tree resembling the genus Dacridium and large pieces rf racius. It should be mencioned that this is the arliest cactus known, and that the spines are found to bo siill flexible. The sands are in other places crowded with fruits something like those met with at Sheppey. Unfortunately the salt contained in them efforesces and splits all these specimens into fragments.

I may just tell you that at Hengistbury Head we have deeper sea deposits, with sharks' teeth and bones. At Highcliff, Barton, we have relics of a sea swarming with life, myriads of fossil shells may be collected on the cliffs, whilst still further on at Hordwell, we have beds showing that the land arose again, affording suitable conditions for the growth of luxuriant palms, and was the haunt of the alligator, turtle, and other reptiles which are now conlined to tropical countries.

F:g. 2 is a view of the Valley of the Bourne at the time referred to above; a description will be given in the next article. (To be continued.)

\section{GEOGRAPHICAL CURIOSITIES}

DURING the meeting of the International Geographical Congress at Paris in 1875 , the National Library opened an exhibition supplementary to that which was held in the Tuileries. Although very rich in documents and modern geographical works, the great national institiation did not wish to show simply a duplicate of the collections exhibited at the Tuileries, and it therefore brought cut only ancient and rare objects which the rules of the c stablishmient wisely forbid to leave the building. Thus it showed to the public neither its great topographical maps, such as those of Cassini, van der Maelen, \&c., nor iis recent atlases, its numerous geological maps, its hydrographic charts of the French, English, and other Admiralty Departments, But, thanks to M. Leopold Delisle,
Administrator-General of the National Library, and to M. E. Cortambert, Librarian of the Section of Maps and Plans, there was exhibited in the magnificent Mazarin Gallery a collection unique of its kind, and to which tive Departmenis of Printed Books, Manuscripts, and Engravinir contributed. The objerts extibiect buto ged generally to Group IV., devoted to Historical Geography and the History of Geography, and comprised, besides ancient and modern works and MSS. treating of geography and its history, ancient maps and globes, instruments used by ancient geographers, astrolabes, sundials, \&c.

The success of the exhibition in the Mazarin Gallery inspired the Administration of the Library with the happy idea of transforming this temporary exhibition into a permanent institution. This has been established in the ground-floor of what is known as the "Salle des Globes," and in the two rooms which look out upon the great court of the Rue Richelieu, has been recently opened to the public who are admitted on Tuesdays from ro to 4 .

Although the limited space at disposal in these apartments has not permitted the transference of all the objects exhibited in the Mazarin Gallery, and although the Departments of Manuscripts and Printed Books have kept possession of some of the valuable documents lent on the occasion of the Geographical Congress, the exhibition is nevertheless of the greatest interest on account of the rarity of the objects which it contains. Space forbids us to give a complete list of the many objects exhibited, though we are able, through the courtesy of the editor of La Natrire, to give illustrations and descriptions of a few of the curiosities. There are nearly 500 objects altogether, and those who desire a complete descriptive catalogue of them should procure No. 178 of the French journal just referred to.

On entering the first room of the exhibition the visitor is at once struck with the large dimensions of the two great globes of Coronelli, made, in I683, by order of the Cardinal D'Estrees, who presented them to King Louis XIV. Ore of the most curious objects shown in this room is a map of the world, probably of the ninth or tenth century. It is a copy of one which appeared in a Commentary on the Apocalypse written by Beatus, a benedictine of the monastery of Valcovado in Leon, who lived in the eighth century. The original of which the one exhibited (Fig. I) is a copy, belongs to the library of Turin. It shows strikingly the wonderful notions which these old monks had of the universe, and especially of the earth in which they dreamed their uneventful lives away. Four winds, represented by the grotesque figures seated upon the skin or leathern bottles, and holding shells in their mouths, indicate not the four cardinal points, but the collateral points, where the sun rises and sets at the summer and winter solstices. The orientation of the map, as was for long the custom in the middle ages, places the east at the top, the west below, the north on the left, and the south on the right. A circular ocean, the old river Oceanos of Homer, surrounds the world. If we examine the interior of this strange mappemonde, Europe will be seen on the left, Africa on the right, and Asia at the top. The Mediterranean is represented by a very regular parallelogram, extending from east to west. A not less regular branch of this sea occupies the place of the Archipelago, the Black Sea and the Sea of Azov, and bounds Europe on the east, the north-east point of the continent being indicated by the words Hic Caput Europe (Europæ). Islands uniformly square are spread over the Mediterranean; we may recognise under strange names, Corcyra, Cyprus, Samos, Sicily, Corsica; the name Tassis, which may also be noticed, designates, no doubt, the City of Tarsus, which the author evidently regards as an island.

In the surrounding ocean appear other islands not less fantastical. On the east the island of Crisa and Algure 